\title{
THE APPLICATION OF THE SEMIOTICS OF QUR'AN TOWARD THE STORY OF THE CHOSEN SERVANTS IN SURAH MARYAM
}

\author{
Zainuddin Soga ${ }^{1}$ \\ Mardan $^{2}$ \\ Achmad Tola ${ }^{3}$ \\ Amrah Kasim ${ }^{4}$ \\ Kamaluddin Abunawas ${ }^{5}$ \\ Alauddin State Islamic University of Makassar, Indonesia ${ }^{1,2,3,4,5}$
}

\begin{abstract}
This study elaborates the application of semiotic theory in Surah Maryam (Maryam). This study is library research. The library research was conducted through various literature studies related to the problem investigated. The approach used is a semiotic approach. The data sources are divided into two; primary and secondary data. The primary data source is the Qur'an (surah Maryam) and the secondary data sources are books of interpretation, semiotics and linguistics. The data collection is done by quoting, adapting, and analyzing the representative literature and relevant to the problems discussed, then reviewing and concluding. The study results showed three forms of semiotic application in Surah Maryam: first, semiotics of significance from Ferdinand de Saussure's (synchronic-diachronic theory). Second, semiotics of communication from Charles S. Peirce's includes iconic, indexical, and symbolic theories. Third, connotative semiotics from Roland Barthes' which consists of denotative meaning and connotative meaning. This study implies that the semiotic reading of the Qur'an prioritizes the interpretation of the text in a synchronic and diachronic, denotative and connotative way. Hopefully, by this reading, religious and Islamic moderation could be achieved.
\end{abstract}

Keywords: Qur'an Semiotics Application; The Story of Servants; Surah Maryam

\section{INTRODUCTION}

Surah Maryam (Maryam) is the $19^{\text {th }}$ surah in the Quran. This surah consists of 98 verses and belongs to the Makkiyah surah because almost all of the verses revealed before the Prophet Muhammad S.A.W migrated to Medina, even before his companions migrated to the land of Habsyi. ${ }^{1}$ According to the history of Ibn Mas'ud, Ja'far bin Abi Talib read the beginning of this Surah Maryam to King Najasyi and his followers when he emigrated with other friends to the land of Habsyi. ${ }^{2}$

This surah is called Maryam because this surah contains the story of Mary, the mother of Prophet Isa A.S. This Surah tells the miraculous birth when Mary gave birth

\footnotetext{
${ }^{1}$ Hamka, Tafsir al-Azhar juz XVI (Cet. I; Jakarta: PT. Citra Serumpun Padi), p.2.

${ }^{2} \mathrm{Abu}$ Ja'far Muhammad Ibn Jarìr al-Ṭabari, Tafsìr al-Tabar̄i Jāmi' al-Bayān 'an Ta'wīl ayy alQur'ān, p. 438.
} 
to Prophet Isa A.S. even though she had never been married. The Birth of Prophet Isa A.S. without a father is proof of Allah's power. ${ }^{3}$

The writers divide the semiotic analysis of the Qur'an in Surah Maryam into eight parts. First, it discusses the prayer of the Prophet Zechariah (Zakaria) A.S., an older man and his barren to have children as prophetic heirs. Second, about the story of Prophet Yahya's obedience to the holy book and his submission to his parents. The third story is directly related to the fourth story. These two stories (III and IV) discuss the sanctity of Mary bint Imran and the birth of Prophet Isa A.S. The public's response toward his birth and the miracle of Prophet Isa A.S., a baby in a cradle that can refute society's vile accusations toward his mother.

The fifth story tells the story of Prophet Abraham (Ibrahim) A.S., who preaches to his pagan father. Then Prophet Abraham A.S. keeps himself away from those who commit shirk. Allah SWT. gave him two sons named Isaac (Ishak) and Jacob (Ya'qub), who became prophets. The sixth discussion talks about the story of Prophet Moses (Musa) A.S. and Prophet Aaron (Harun) A.S. This story discusses the two glories of Prophet Moses A.S. He can to talk to Allah SWT., the creator and Prophet Moses A.S blessed with a brother, namely Aaron A.S. who becomes a prophet.

The seventh discussion tells about the story of Prophet Ishmael (Ismail) A.S. This story tells about the persistence of Prophet Ishmael A.S. to keep his promises. Prophet Ishmael also ordered his family to do prayers and pay zakat. The eighth discussion tells about the story of the Prophet Idris A.S., who loves the truth, and then Allah raises his glory to the highest dignity.

\section{LITERATURE REVIEW}

\section{A. Definition of Semiotics of the Qur'an}

The word "semiotics" originated from the Greek "seme", as in semeiotikos, which means interpreter of signs. ${ }^{4}$ As a discipline, semiotics refers to the science (theory) of symbols and signs. ${ }^{5}$

The early pioneer of semiotics was Plato (427 BC), who examined the origins of language in Cratylus. Aristotle also pays attention to nouns in his books Poetics and On Interpretation. ${ }^{6}$ According to Alex Sobur in the history of linguistics, the terms semiotics and semiology have other terms, namely, semasiology, semimik, and semik. ${ }^{7}$ All of these terms refer to the field of study which learns about the meaning of a sign or symbol.

The word semiotics also has a similar meaning to the word sima in Arabic. The word sign in the Qur'an is called sima, as in surah al-Fath/48: 29.

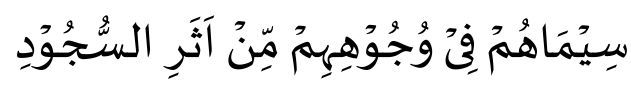

\footnotetext{
${ }^{3}$ Hamka, Tafsir al-Azhar juz XVI, p.3.

${ }^{4}$ Ali Imran, Semiotika al-Quran: Metode dan Aplikasi terhadap Kisah Yusuf (Cet. I; Yogyakarta: Teras, 2011), p. 9.

${ }^{5}$ Kamus Besar Bahasa Indonesia (Cet. I; Jakarta: Balai Pustaka, 2001), p.1029.

${ }^{6}$ Ali Imran, Semiotika al-Quran: Metode dan Aplikasi terhadap Kisah Yusuf, p. 9.

${ }^{7}$ Alex Sobur, Semiotika Komunkasi (Cet. IV; Bandung: Remaja ROsdakarya, 2009), p. 11.
} 
Meaning:

"Their marks are on their faces from the effects of prostration."

In this verse, al-Zamakhsyari (1143 AD) commented, the word sima in verse means a sign; it refers to the marks of prostration on the face. ${ }^{9}$ In addition, the Qur'an has explained a lot about signs. The sign in the Qur'an is also called al- $\bar{A} y a h$, for example, in surah al-Mu'minun/23: 50.

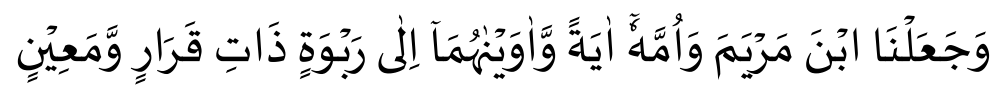

Meaning:

"And we made Mary's son and his mother a sign, and we sheltered them on high ground with security and flowing springs. "lo

The semiotic approach in the study of Qur'an interpretation implies an effort to study and interpret the Qur'an by the way it works and the functions of signs in the Qur'an text as the orientation of the study.

\section{B. Semiotic Theories}

1. Semiotics of significance by Ferdinand de Saussure's

Ferdinand de Saussure is a linguist. He got the title of father of linguistics from the early linguists. Besides, he is also known as the originator of structuralism. He introduced several distinctions that play an essential role in his semiology, such as langage-langue-parole, signifier-signified, synchronic-diachronic, and syntagmaparadigm. ${ }^{11}$ With the number of these distinctions, Saussure wants to explain that language is a system that is interrelated to one another. The meaning of language as a system becomes the basis for understanding the structure. The word structure in structuralism is always accompanied by the entire context of the above distinctions.

2. Communication Semiotics by Charles Sander Peirce

In studying the objects, C.S Peirce divides his semiotics into three parts as follows:

a) Icon: something that functions as a marker that is similar to the shape of the object (seen in picture or painting

b) Index: something that performs the function as a marker that indicates the signifier.

\footnotetext{
${ }^{8}$ Kementrian Agama RI, Alquran dan Terjemahnya (Cet. X; Bandung: CV Penerbit Dipenigoro, 2013), p. 515.

${ }^{9}$ Abū al-Qāsim Maḥmūd bin 'Umar bin Muhammad al-Zamakhsyarī, al-Kasysyāf 'an Haqā'iq

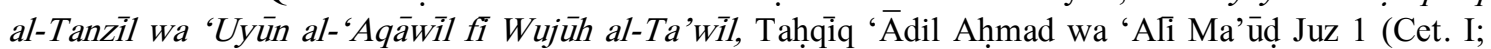
Riyāḍ: Maktabah al-‘Abayikān, 1998 M), p. 550.

${ }^{10}$ Kementrian Agama RI, Alquran dan Terjemahnya, p. 46.

${ }^{11}$ Stephanus Aswar Herwinarko, Semiologi; Kajian Teori Tanda Saussuran antara Semiologi Komunikasi dan Semiologi Signifikasi (Cet. I; Yogyakarta: Jalasutra, 2010), p. 45.
} 
c) Symbol: something that performs the function as a marker which has been commonly used in society. ${ }^{12}$

\section{Connotation Semiotic by Roland Barthes}

Barthes is also known as connotative semiotics. He divides the meaning into two parts, namely denotative and connotative meaning. ${ }^{13}$ The denotative meaning is the meaning that points directly to the reference or primary meaning. The connotative meaning is an additional meaning to the primary meaning in the form of a particular taste or image value. ${ }^{14}$

\section{RESEARCH METHODOLOGY}

This study is library research. It is conducted through various literature studies related to the problem investigated. ${ }^{15}$ The approach used was a semiotic approach. The data sources are divided into two, namely primary and secondary data. The primary data source is the Qur'an (surah Maryam) and the secondary data sources are books of interpretation, semiotics and linguistics. The data collection is done by quoting, adapting, and analyzing the representative literature and has relevance to the problems discussed, then reviewing and concluding. ${ }^{16}$

\section{FINDINGS AND DISCUSSION}

A. The Application of Semiotic Theory in The Story of The Prophet Zechariah A.S.

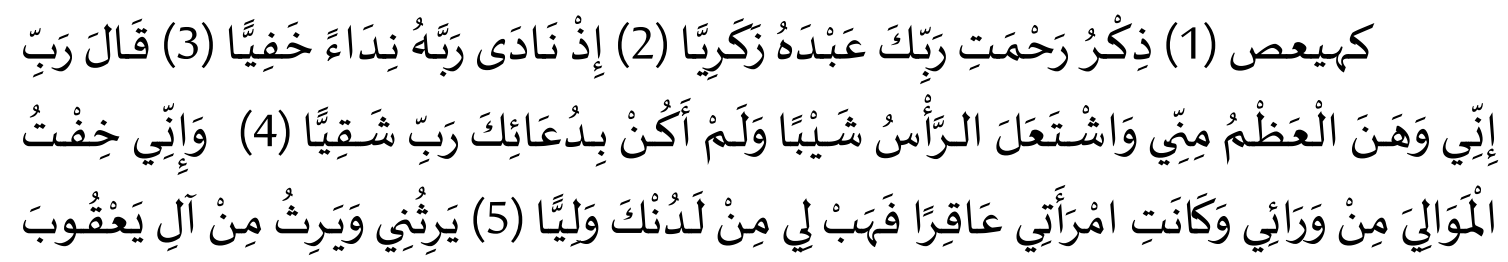

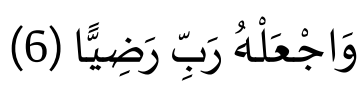

Meaning:

"Kaaf Haa Yaa 'Ayn Shaad. This is a reminder of your Lord's mercy to His servant Zachariah (Zakariah), when he cried out to his Lord privately, saying, "My Lord! Indeed my bones have become brittle, grey hair has spread across my head, but I have never been disappointed in my prayer to You, my Lord!. And I am concerned about the faith of my relatives after me since my wife is barren.

${ }^{12}$ Puji Santosa, Ancangan Semiotik dan Pengkajian Susastra, p. 13.

${ }^{13}$ Dadan Rusmana, Filsafat Semiotika, p. 200.

${ }^{14} \mathrm{M}$ Ardiansyah, Petualangan Semiologi, p. 7.

${ }^{15}$ Sugiono, Metodelogi Penelitian Kuantitatif Kualitatif dan R\&D (Cet. VII; CV.Alvabeta, 2009), p. 213.

${ }^{16}$ Noeng Muhadjir, Metodologi Penelitian Kualitatif (Cet. VIII; Yogyakarta: Rake Sarasin, 1996), p. 49. 
So grant me, by Your grace, an heir, who will inherit prophethood from me and the family of Jacob (Jacob), and make him, O Lord, pleasing to You." 17

\section{Semiotic analysis of C.S. Peirc}

The verses in Surah Maryam do not explicitly mention how old the Prophet Zechariah A.S was. However, in indexical, we can know the age of Prophet Zechariah A.S. We can read the indications from the phrase in the fourth and fifth verses. The phrase of ألْعَظُُْ means the bones are weak. When the bones are weak, the other body limbs must also be weak because the bones are the crutch of the body.

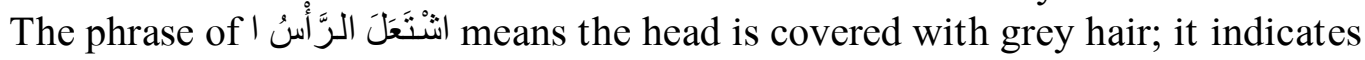
that the hair of the Prophet Zechariah A.S. has turned grey. Grey hair is a sign of weakness and ageing, a messenger of death, and a warning to its owner. ${ }^{18}$ Prophet Zechariah A.S. put his trust in Allah with his weaknesses. It includes the way of tawasul that Allah SWT loves because it shows an attitude of detachment from his abilities and relies on Allah SWT's power. The semiotic analysis of C.S. Peirce, which consists of icons, indexes, and symbols, can be seen below.

\begin{tabular}{|c|c|c|}
\hline Icon & Indexes & Symbols \\
\hline $\begin{array}{l}\text { Prophet } \\
\text { Zechariah } \\
\text { A.S. }\end{array}$ & 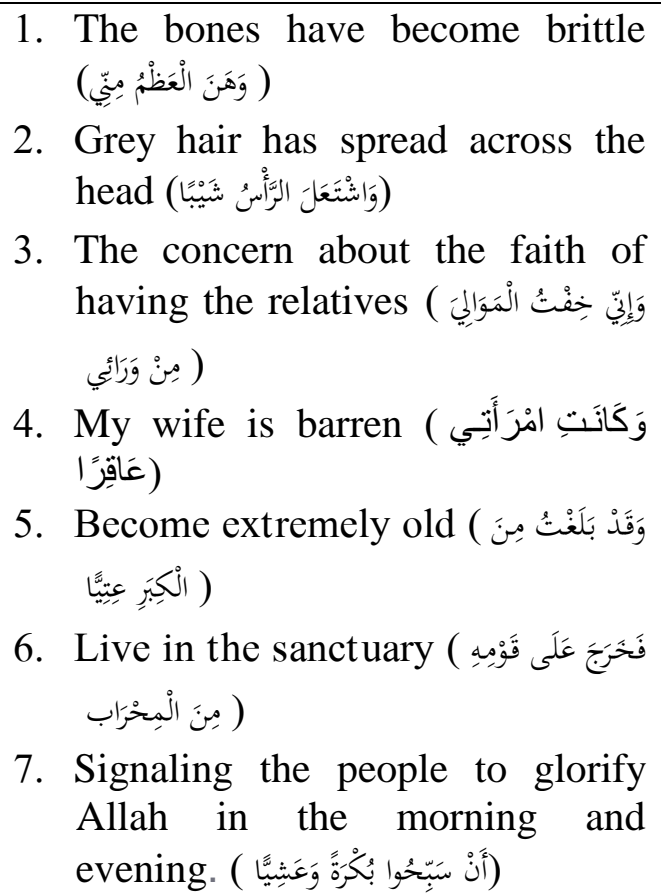 & $\begin{array}{l}\text { 1. Brittle bones and grey hair } \\
\text { symbolize ageing. Weak } \\
\text { bones and grey hair } \\
\text { symbolize ageing. } \\
\text { 2. Sanctuary symbolizes } \\
\text { simplicity. }\end{array}$ \\
\hline
\end{tabular}

The icons in the table define the figure of Zechariah. His bones are brittle, and his hair turned grey. He has a barren wife, so he is worried that he will not raise children. Besides, he lives in the sanctuary, which symbolizes simplicity, but those cases do not neglect him to warn his people.

\footnotetext{
${ }^{17}$ Kementrian Agama RI, Alquran dan Terjemahnya, p. 305.

${ }^{18}$ Abū Ja'far Muhammad Ibn Jarīi al-Ṭabarí, Tafsìir al-Tabar̄i Jāmi' al-Bayān 'an Ta'wīl ayy alQur'ān, p. 446.
} 
2. The connotation semiotic analysis by Roland Barthes

The writers have explained the first verse using the heuristic reading of the scholars to return the meaning to Allah SWT. Ibn Kathir in his interpretation does not explain the letter of al-muqattha'ah. ${ }^{19}$ Al-Zamakhsyari in his interpretation only explains how to read those five letters. ${ }^{20}$ According to the writer of the semiotic reading on the first verse in Surah Maryam, it uses the connotations semiotic analysis of Raland Barthes, so the five muqattha'ah letters can be analyzed.

The letter Kaf is a fragment of Allah's name al-Kabir, which means the Greatest. The letter $\mathrm{Ha}$ is a fragment of the letters of the name of Allah al-Hadi which means giving guidance. The letters $Y a$ and 'Ain are taken from the word al-'Aziz, which means the Almighty or the Mighty. The letter Sad comes from the word alSadik which means the Most Honest. Al-Tabari said that the letter Kaf comes from the name al-Malik, which means the Almighty King. The letter $\mathrm{Ha}$ is at the end of Allah's name. The letters $Y a$ and 'Ain come from al-Ażiz, which means the Almighty or Mighty. While the letter Sad comes from the word al-Musawwir, which means the One who gives shape and form to something. ${ }^{21}$ Although the scholars explained some of the takwil of these letters, they ended the explanation by returning the meaning to Allah SWT. Allah 'alam bimurädifih

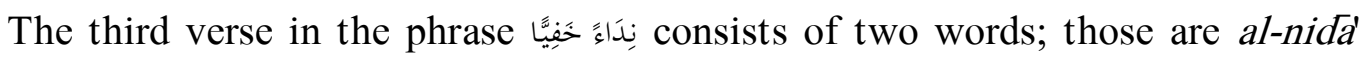
and al-khafíy. Etymologically, al-nida' means an exclamation. ${ }^{22}$ Al-khafíy means hidden, ${ }^{23}$ al-nidan khafiyan means hidden exclamation. In Roland Barthes' semiotic analysis of connotation, the hidden exclamation contains the meaning of the prayer at night. Prophet Zechariah A.S. pray to his Lord in a low and hidden voice because of fear of riya. ${ }^{24}$

B. The application of semiotic theory to the story of the Prophet Yahya A.S.

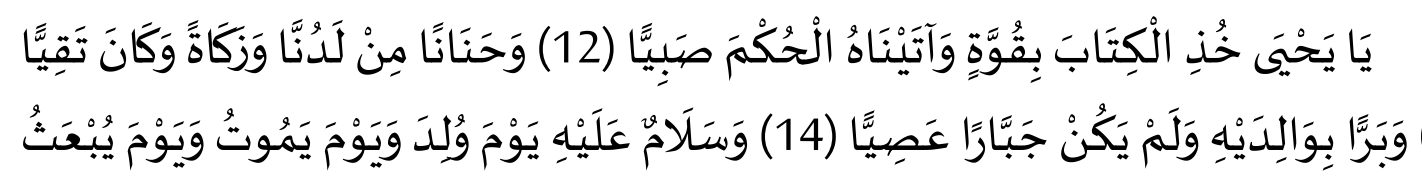

\footnotetext{
${ }^{19} \mathrm{Abū}$ al-Fidā' Ismā'il Ibn 'Umar Ibn Kașīr, Tafsìir Ibn Katsīì, p. 206.

${ }^{20} \mathrm{Abū}$ al-Qāsim Mạ̣mūd bin 'Umar bin Muhammad al-Zamakhsyarì, al-Kasysyāe 'an Haqā’iq

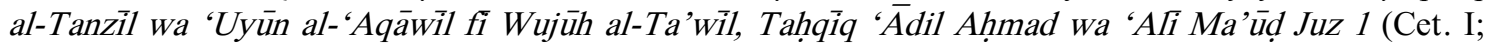
Riyāḍ: Maktabah al-'Abayikān, 1998 M), p. 5.

${ }^{21}$ Hamka, Tafsir al-Azhar juz XVI, p. 3.

${ }^{22}$ Mahmud Yunus, Kamus Arab-Indonesia (Jakarta: PT Mahmud Yunus wa Dzurriyyah, 2010), p. 447.

${ }^{23}$ Mahmud Yunus, Kamus Arab-Indonesia (Jakarta: PT Mahmud Yunus wa Dzurriyyah, 2010), p. 119. Qur'ān p. 448.

${ }^{24} \mathrm{Abu}$ Ja'far Muhammad Ibn Jarìr al-Ṭabarì, Tafsìr al-Ṭabài Jāmi' al-Bayān 'an Ta'wīl ayy al-
} 
Meaning:

"It was later said, "O Yahya! Hold firmly to the Scriptures." and We granted him wisdom while he was still a child, as well as purity and compassion from Us. And he was God-fearing and kind to his parents. He was neither arrogant nor disobedient. Peace be upon him the day he was born, and the day of his death, and the day he will be raised back to life. ${ }^{25}$

1. Semiotic reading by C.S. Peirce

\begin{tabular}{|c|c|c|}
\hline Icon & Indexes & Symbols \\
\hline $\begin{array}{c}\text { Prophet } \\
\text { Yahya } \\
\text { A.S. }\end{array}$ & 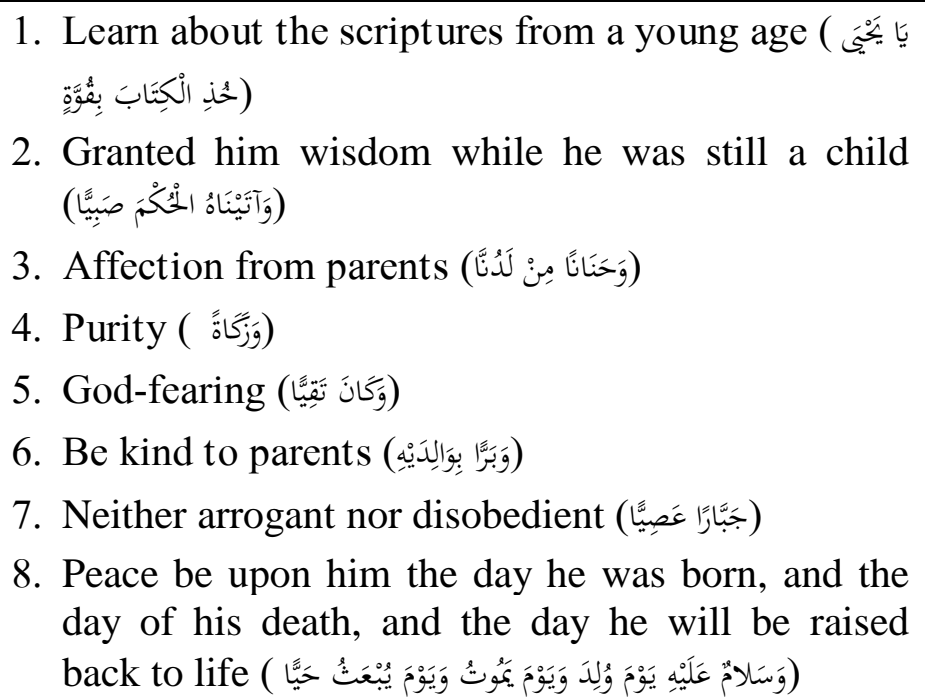 & $\begin{array}{l}\text { 1. The word } \\
\text { symbolize } \\
\text { sincerity } \\
\text { 2. Wisdom } \\
\text { symbolize } \\
\text { discretion }\end{array}$ \\
\hline
\end{tabular}

The table above implies the characteristics of the Prophet Yahya A.S. and the retaliation he gets from these traits.

a) Learn about the script ures could get the wisdom

b) Be kind to parents could lead us to become parents' favorite child

c) Purify ourselves, not to be arrogant, do not commit immorality, the retaliation is to become a pious human being and be saved on the day of resurrection.

3. The connotation semiotic analysis by Roland Barthes

Connotation is a feeling or idea that accompanies a word feeling or emotion. According to Barthes, meaning cannot stop at the signifier and the sign. For Barthes, the formulation from Ferdind de Saussure is the first meaning because culture can also influence the meaning, or it is known as connotative meaning. Therefore, Roland Barthes formulated the characteristics of denotation and connotation. The characteristics of denotation: natural, literal, explicit, clear, reasonable. Meanwhile, the characteristics of connotative are intuition, subjective, implicit, emotional, and cultural. The story of the Prophet Yahya A.S. in Surah Maryam starting from the twelfth verse to the fifteenth verse.

${ }^{25}$ Kementrian Agama RI, Alquran dan Terjemahnya, p. 306. 
The semiotic analysis of connotation in this story is found in the twelfth verse. The word قوة means strength. ${ }^{26}$ The denotative meaning of the phrase احُذِ الْكَتَابَ بِقِوَّة is Allah SWT. ordered the Prophet Yahya A.S. to take the Torah sincerely. The connotative meaning of the phrase is Allah SWT. ordered the Prophet Yahya A.S. to learn about the Torah and practice it earnestly.

\section{The application of semiotic theory to the story of Mary}

1. Semiotic analysis by C.S. Peirce

\begin{tabular}{|c|c|}
\hline Icon & Indexes \\
\hline $\begin{array}{l}\text { Mary bint } \\
\text { Imran }\end{array}$ & 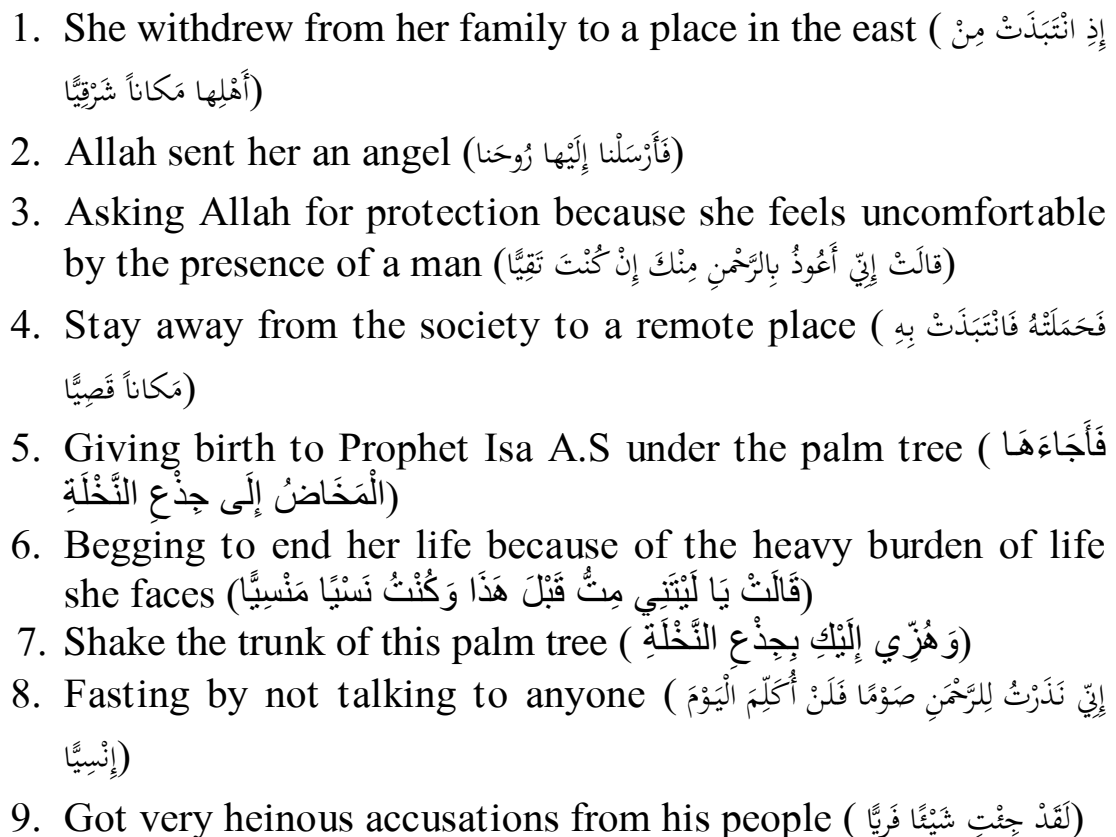 \\
\hline
\end{tabular}

From this icon, we can see from the index the story of Mary bint Imran when Jibril visited her. How difficult was it when she was pregnant and gave birth to Prophet Isa A.S. We can also see how the people treated her with very heinous accusations. Then, the writers include a table of the Angel Gabriel (Jibril) Icons and their indexes and symbols.

2. Roland Barthes' semiotic analysis of connotations

a) Eastern Place

The story of Mary begins in the sixteenth verse. In this verse, we could find the phrase مَكاناً شَرَرْيَّا. In denotation, it means a place in the east. The connotation meaning of the phrase is that Mary distanced herself from her family for worship to Allah. Mary made the east as the Qibla. Then the Christians followed Mary's steps in worship,

\footnotetext{
${ }^{26}$ Mahmud Yunus, Kamus Arab-Indonesia (Jakarta: PT Mahmud Yunus wa Dzurriyyah, 2010), p. 362 .
} 
alone and facing the east. Al-Tabari said Christians worship by facing the east; this is due to their belief that facing the east is better than places facing the west. ${ }^{27}$

b) Spirit (Ruh)

The seventeenth verse explains that Allah SWT. sent the spirit (angel Gabriel) to meet Mary. Etymologically, the word spirit means a living being that has nobody, but it has thoughts and feelings (angels, jinn, demons, etc). ${ }^{28}$ The word spirit appears 21 times in 20 verses in the Qur'an. The word spirit in several verses in the Qur'an means the angel Gabriel. The angel Gabriel is referred as ru $u h, R \bar{u} h$ al-Quds, Rüh alAmin and Rühuna. The word rüh, which means the angel Gabriel is found in several other verses such as he was brought down by Rüh al-Amin (Jibril), into your heart (Muhammad) so that you may become one of those who warn. (Surah al-Syu'ara: 193194). In addition, the angel Gabriel is also called as the Rasūl (messenger) as described in the following verse, as well as in Surah al-Takwir: $19 .{ }^{29}$

The Qur'an has two different words for angel (malak) and the plural for angels (mala'ika). Interestingly, the word rüh does not have a plural form in the Qur'an. It implies that, unlike the angels, there is only one spirit, namely Gabriel. The phrase "Our Spirit" in the seventeenth verse indicates that the spirit is a single being, not a trinity.

The interpreters argue that the spirit is essentially an angel, but this angel has the specialty out of the other angels. The Qur'an always explains about angels in the plural when describing their task of conveying messages, while Gabriel is mentioned separately. Several verses point to the tasks that were explicitly given to Jibril.

Three verses mention rūh and angels together. It shows that there is a difference between them. First, Surah al-Ma'ärij (70): 4: "Angels and the Spirit ascend to God in a day which rated as fifty thousand years". Second, Surah al-Naba '(78): 38: "On the day (of Judgment) when the Spirit and the angels stand in rows; they do not speak except to whom that had given the permission." Third, Surah al-Qadr (97): 4: "The angels and the Spirit descend on the glory night with God's permission"

\section{The application of semiotic theory to the story of Prophet Isa A.S}

\section{Semiotic Reading by C.S. Peirce}

The fourth story's table of icons, indexes, and symbols describes that Prophet Isa A.S is a human. It can be analyzed from the index of Prophet Isa; all of the indexes symbolize humans (prophets). The Prophecy of Isa A.S. in the Qur'an is always consistent. It is in contrast to the biblical verses in which, in several verses, Isa A.S. is called a messenger. In another verse, Isa A.S is called God so that the verses of the Qur'an are more consistent than the verses of the Bible.

The signs that indicate Isa A.S. as a human, that is, he ordered his people to worship Allah, simply because his Lord is also their Lord. He also prayers like the servants of Allah in general and pays zakat. In addition, Prophet Isa A.S. has noble

${ }^{27}$ Abū Ja'far Muhammad Ibn Jarìr al-Ṭabarì, Tafsìir al-Tabarì Jāmi' al-Bayān 'an Ta'wīil ayy alQur'ān, p. 495.

${ }^{28} \mathrm{KBBI}$, p. 239

${ }^{29}$ Lihat, Kementrian Agama RI, Alquran dan Terjemahnya, p. 586. 
qualities such as filial piety to his parents, bringing blessings wherever he is, speaking with good words, and not being arrogant.

\begin{tabular}{|c|c|}
\hline Icon & Indexes \\
\hline \multirow{7}{*}{$\begin{array}{l}\text { Prophet } \\
\text { Isa A.S. }\end{array}$} & 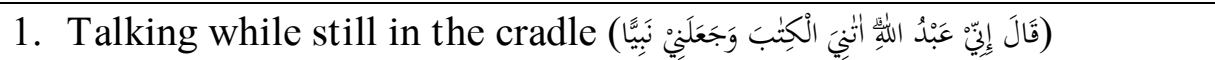 \\
\hline & 2. made him a blessing wherever he goes (وَجَعَلَنْ مُبرِكًا أَيْنَ مَا كُنْتُ \\
\hline & 3. Ordered to do prayers and pay zakat, be devoted to his mother, and \\
\hline & 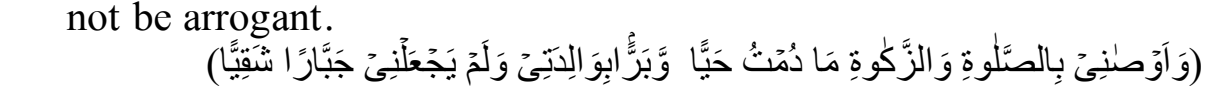 \\
\hline & 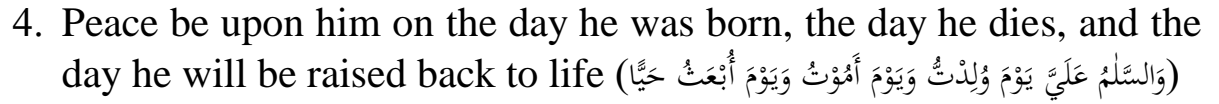 \\
\hline & 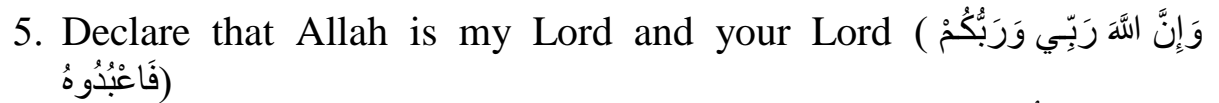 \\
\hline & 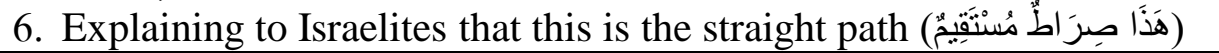 \\
\hline
\end{tabular}

The table explains that the icon is Prophet Isa A.S. Meanwhile, the characteristics and practices can be seen in the index column. If it is analyzed in-depth, we can classify two characteristics of Prophet Isa into two symbols, namely the symbol of man and the symbol of the Prophet. Then, the practices of Prophet Isa A.S. in Surah Maryam as follows:

a) The bearer of blessings.

b) Do the prayers and pay for zakat.

c) Devoted to his mother.

d) Not to be arrogant.

e) Allah does not declare him as a child of God, the symbol of Prophet Isa A.S. is as a human.

f) Declare that Allah is my Lord and your Lord the symbol of Prophet Isa A.S. is as a human.

g) Ordering his people to worship Allah and explaining to them that this is the straight path (the righteousness), a symbol of him as a prophet.

The rewards may include the miracles given to Prophet Isa A.S, such as: First, talking while still in the cradle and being the bearer of the gospel message; those are the prophetic symbols. Second, Peace be upon him on the day he was born, the day he died, and the day he will be raised back on the day of resurrection.

2. Ferdinand de Saussure's synchronic-diachronic semiotic analysis

Ferdinand de Saussue is the father of linguistics and semiotics. He initiated four semiotic theories: langage distinction, langue, and parole, signifier distinction, signified, syntagmatic and paradigmatic distinction, synchronic and diachronic distinction. The synchronic study is the descriptions of the particular state of the language (at one point). ${ }^{30}$ The study tends to be horizontal because it examines the language at a particular time, for example, investigating the Indonesian language used in 1945.

The diachronic study is a sub-discipline of linguistics that investigates the development of a language over time. This study tends to be vertical; for instance, it

\footnotetext{
${ }^{30}$ Alex Sobur, Semiotika Komunikasi, p. 53.
} 
examines the development of the Indonesian language from the pre-independence period, the independence period, to the millennial era. Examples of synchronic and diachronic studies in Surah Maryam are found in verse 28.

In the phrase: يا أخت هارون (Aaron, my brother!). People call Mary Aaron's brother, but scholars have different opinions about the title of Aaron's brother. Did Aaron refer to Prophet Aaron A.S. or someone else? Here, we can apply synchronic and diachronic studies with data sources from the interpretations written by scholars. From the results of the writers' reading, two opinions interpret the verse.

The twenty-eighth verse explains the title for Mary as "Aaron's brother".

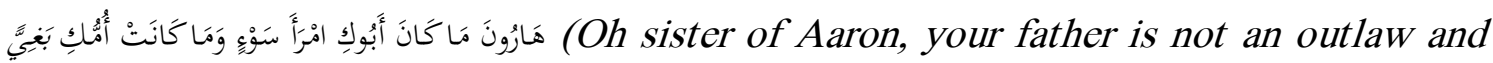
your mother is not an adulterer). There are three interpretations of the meaning of "Aaron's brother", firstly, Aaron is the brother of Prophet Moses A.S. Second, Aaron was a pious man who lived at the same time as Mary. Third, Aaron was a wicked man.

The first reason Mary is titled "Aaron's brother" is because it has become a tradition for an obedient adherent of religion such as Judaism, Christianity, or Islam; they like to put the name of the Prophets on their children's names. ${ }^{31}$ The second argument explains that Aaron is a pious person who lived at the same time as Mary. He is precisely like Mary because he had been devoted to a sanctuary from childhood, so people used to call Mary Aaron's brother. Then, they equated Mary with Aaron.

The third opinion says that Aaron is a wicked person or a person who sinned. People call Mary Aaron's brother (the wicked) because they want to equate what Mary (adultery) has done to what Aaron (the wicked) did. According to the writers, the meaning of "Aaron" is the brother of the Prophet Moses A.S.

The writers prefer the first opinion because in the next verse or the $53^{\text {rd }}$ verse in the story of Prophet Moses A.S. Allah SWT explicitly mentions the name of Aaron as the brother of Prophet Moses A.S. According to the writers, the purpose of semiotics is tending to restore the meaning to the text than the interpretation meaning. With a diachronic reading of Ferdinand de Saussure's semiotics, we can understand that the contextual meaning of "brother Aaron" is "descendants of the prophet Aaron A.S."., We will not be able to understand the verse in depth because it is only in textual or the synchronic reading.

\section{E. The application of semiotic theory in the story of Prophet Abraham A.S.}

1. Semiotic reading by C.S. Peirce

\begin{tabular}{|c|c|c|}
\hline Icon & Indexes & Symbol \\
\hline $\begin{array}{l}\text { Prophet } \\
\text { Abraham } \\
\text { A.S }\end{array}$ & 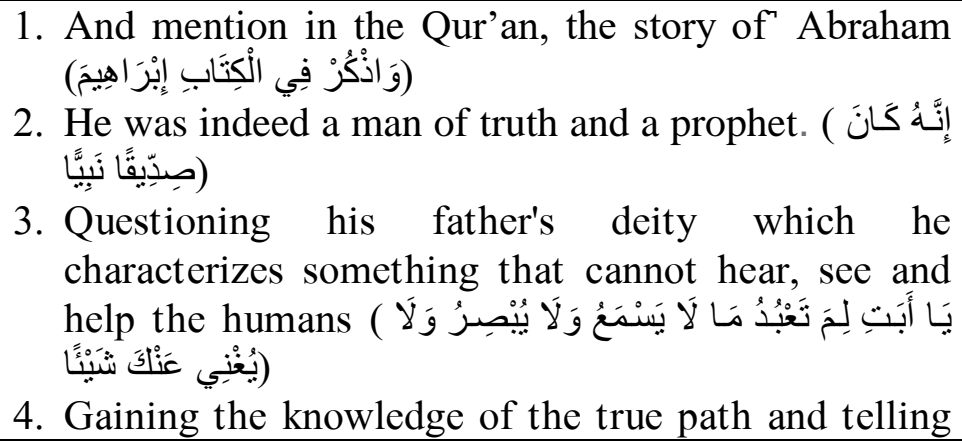 & $\begin{array}{l}\text { Prophet } \\
\text { Abraham A.S. } \\
\text { symbolizes the } \\
\text { father of the } \\
\text { prophets. }\end{array}$ \\
\hline
\end{tabular}

\footnotetext{
${ }^{31}$ Hamka, Tafsir al-Azhar juz XVI, p. 27.
} 


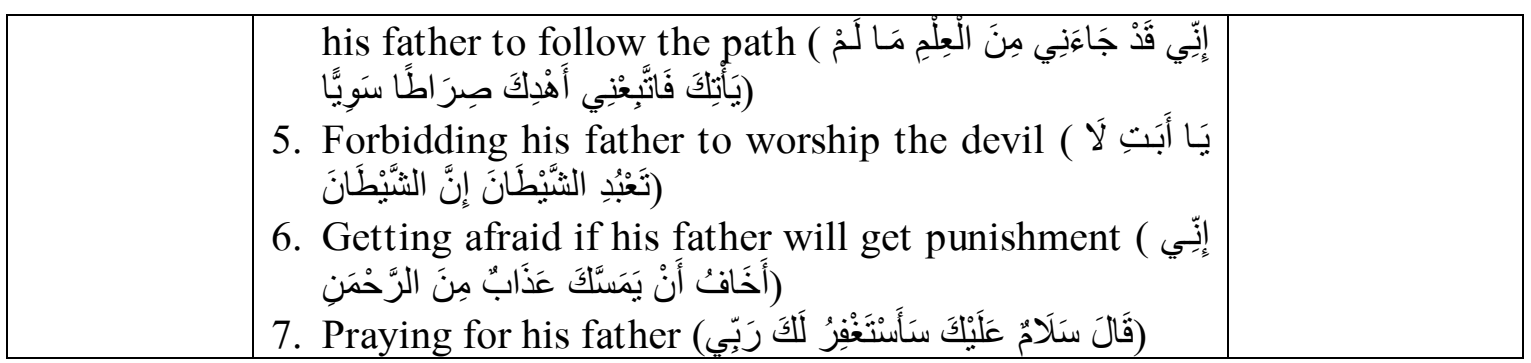

The personality of Prophet Abraham A.S. can be seen in the index. The table explains that Prophet Abraham A.S. has the following characteristics:

a) Holding the title of al-S $\mathbf{i d d} \bar{i} k$. it refers to a person who justifies anything that comes from Allah SWT.

b) Forbidding his father to worship the cult.

c) Praying for his father to be safe from the punishment of Allah SWT

The story of Prophet Abraham A.S. in surah Maryam starting from verse forty one to fifty. In the forty-second verse, the Qur'an uses the phrase "ya Abati", when the Prophet Abraham A.S. said to his father: يَأَبَتِ (O my father). The phrase "ya Abati" has a connotation meaning. This expression has a subtle and reverent meaning.

In the story of Prophet Abraham A.S. The Qur'an does not use the expression "ya Wā lid" or "ya Abi", even though these three words have the same meaning. Here, it can be seen that the semiotics of the Qur'an have beautiful sentences arranged into expressions.

\section{F. The application of semiotic theory in the story of the Prophet Moses A.S.}

There are many stories of Prophet Moses A.S. in the Qur'an. One of the stories is described in Surah Maryam, the fifty-first to the fifty-third verses. The writers find two semiotic theories that can be applied in this story: Charles Sanders Peirce's semiotics and Roland Barthes' connotative semiotics.

1. Semiotic by C.S. Peirce.

\begin{tabular}{|c|c|}
\hline Icon & Indexes \\
\hline Prophet Moses & 1. The story is mentioned in the Qur'an (وَاذْكُمْ فِي الْكِتَابِ مُوسَىى) \\
\hline A.S. & 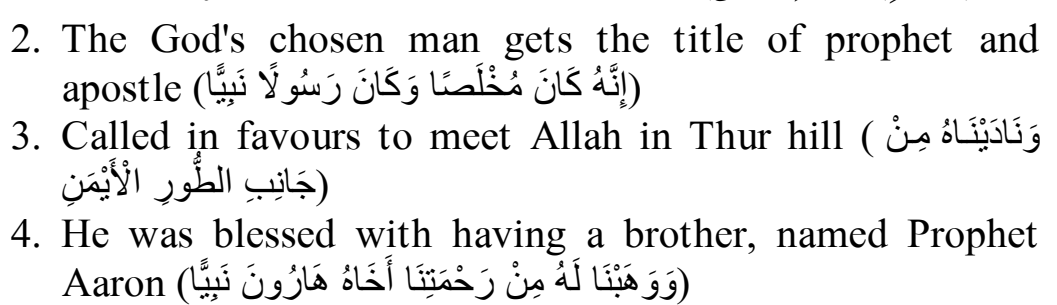 \\
\hline
\end{tabular}

The table above explains that the icon is Prophet Moses A.S. The indexes show that Prophet Moses A.S. had a call from Allah swt. to the hill of al-Thur. Prophet Moses A.S. gets the title Kalamullah which symbolizes that he is talking directly to Allah SWT. on Thur hill without the intermediary of the angel Gabriel.

2. The Connotation of the right side of al-Thur hill

The fifty-second verse describes the command of Allah SWT. to Prophet Moses

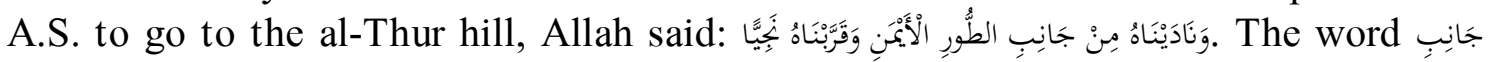


means side. ${ }^{32}$ The word الأيمن comes from the word اليمين which refers to the right side. ${ }^{33}$ The right side refers to the right side of the Prophet Moses because the hill does not have right and left side. Al-Thur is a hill located in the Sinai Peninsula; it is a place for Prophet Moses A.S. to accept the Torah from Allah swt. ${ }^{34}$

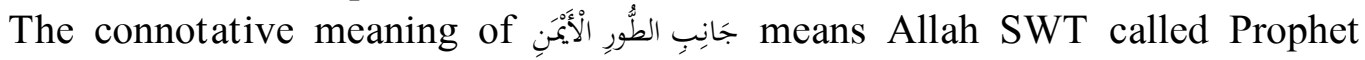
Moses A.S. to the hill of al-Thur. The right side refers to the right side of the Prophet Moses because basically, the hill has no right side. The right side is a symbol as a marker. The sign refers to the burning fire. The fire is a sign where Allah SWT commanded Moses A.S to talk to him without the intermediary of the angel Gabriel. ${ }^{35}$

\section{G. The Application of semiotic theory in the story of the Prophet Ishmael A.S.}

The story of Prophet Ishmael A.S. in Surah Maryam begin from the fifty-fourth verse. In this story, the writers only find one semiotic theory which can be applied. The theory is about the semiotic theory of C.S. Peirce that is divided into three such as icon, index, and symbol. The relationship between the story of Prophet Ishmael and the previous stories are:

1. Prophet Ishmael A.S. is a servant and messenger of Allah SWT

2. Servitude to Allah SWT. which realized by obedience

3. In previous stories, it was explained about the obligation to serve parents, while in the story of Prophet Ishmael A.S. The Qur'an explains the responsibility of a father to his family.

\begin{tabular}{|c|c|}
\hline Icon & Indexes \\
\hline Prophet Ishmael A.S & 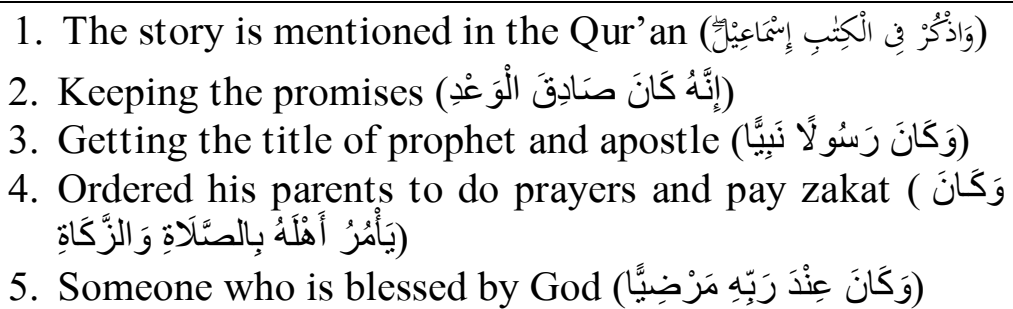 \\
\hline
\end{tabular}

The table above explains the characteristics of Prophet Ishmael A.S. The characteristics of Prophet Ishmael are keeping the promises, getting the title of Prophet and Apostle from Allah SWT. Ordered his family to do prayers and pay zakat, so that he became a human who was pleased by Allah SWT.

\footnotetext{
${ }^{32}$ Mahmud Yunus, Kamus Arab-Indonesia (Jakarta: PT Mahmud Yunus wa Dzurriyyah, 2010), p. 92.

${ }^{33}$ Mahmud Yunus, Kamus Arab-Indonesia (Jakarta: PT Mahmud Yunus wa Dzurriyyah, 2010), p. 510.

${ }^{34} \mathrm{Abū}$ al-Fidā Ismā'il Ibn 'Umar Ibn Kaṣīr, Tafsīir Ibn Katsīir (Miṣr: Dār Ibn Jauz̄i, 1431 H), p. 215.

${ }^{35}$ Abū al-Fidā Ismā'il Ibn 'Umar Ibn Kaṣìr, Tafsīir Ibn Katsìir (Miṣr: Dār Ibn Jauz̄i, 1431 H), p. 215.
} 


\section{H. The Application of semiotic theory in the story of the Prophet Idris A.S.}

1. Semiotic by C.S. Peirce.

\begin{tabular}{|c|c|}
\hline Icon & Indexes \\
\hline Prophet Idris & 1. The story is mentioned in the Qur'an (وَاذْكُر فِ الْكِنَبِ إِدريس) \\
\hline & 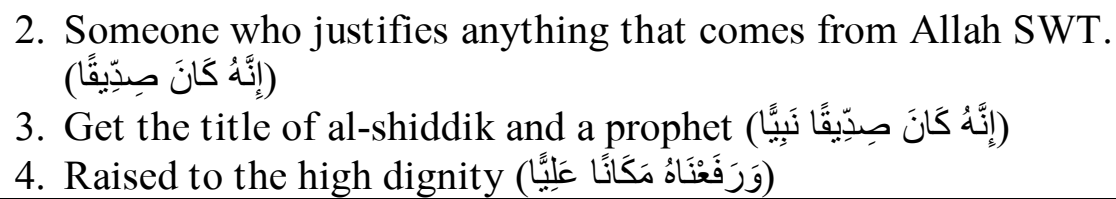 \\
\hline
\end{tabular}

The table above explains the characteristics of the Prophet Idris A.S. His characteristics are the person who justifies anything that comes from Allah, he is a prophet, and he is raised to the high dignity

2. Semiotic analysis of the connotation name "Idris"

Al-Zamakhsyari mentions in his interpretation al-Kasysyäf that the mention of Idris is not because the person frequently examines the holy book (سمي إدريس, لكثرة دراسته كتاب

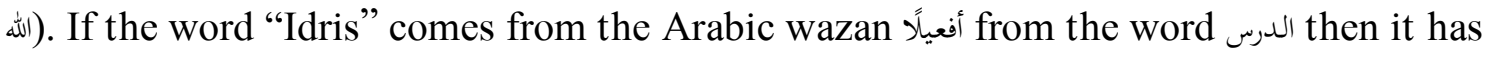
tanwin. However, the name Idris is not munsarif because the name Idris mamn $\bar{u}$ ' mina al-sarf shows the name as a'jamiyyun which means a non-Arabic name as the words

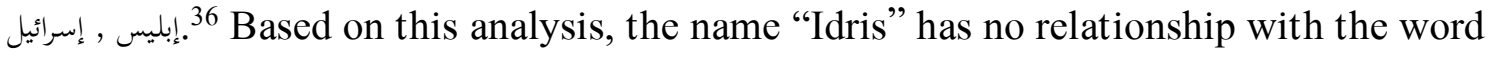
al-dars, even though the word has a morpheme affinity with the word examine (درس (درئس).

3. The meaning of high places

The word المكان العلي comes from two words namely al-makān which means place, dignity, rank, power. ${ }^{37}$ The word المكان العلي means something high. ${ }^{38}$ The phrase means a high dignity. The connotative meaning of the fifty-seventh verse is that Allah SWT. raised the dignity of Prophet Idris A.S. when he was alive and when he had died. The high dignity from Allah SWT is given when he is alive. Allah SWT gives him 30 suhuf. He was also the first person who wrote using a pen, an expert in astrology and arithmetic and the first to sew clothes while worn clothes are made from animal skins.

Ibn Kathir mentions in his interpretation that Allah SWT. raised Prophet Idris A.S. to the sky before he died as done to Prophet Isa A.S. ${ }^{39}$ Al-Zamakhsyari mentioned that Prophet Idris A.S. had been raised to the fourth heaven. When Rasulullah S.A.W . doing mi'raj, he met the Prophet Idris A.S. in the fourth heaven. ${ }^{40}$

\footnotetext{
${ }^{36} \mathrm{Abū}$ al-Qāsim Maḥmūd bin 'Umar bin Muhammad al-Zamakhsyarī, al-Kasysyāf 'an Haqā'iq

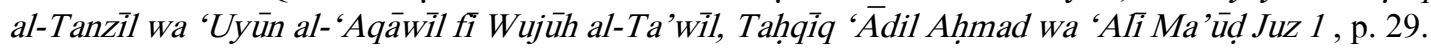

${ }^{37}$ Mahmud Yunus, Kamus Arab-Indonesia (Jakarta: PT Mahmud Yunus wa Dzurriyyah, 2010), p. 426.

${ }^{38}$ Mahmud Yunus, Kamus Arab-Indonesia (Jakarta: PT Mahmud Yunus wa Dzurriyyah, 2010), p. 278.

${ }^{39}$ Abū al-Fidā Ismā'il Ibn 'Umar Ibn Kașīr, Tafsìir Ibn Katsīì, p. 237.
} 


\section{CONCLUSIONS AND IMPLICATION}

\section{A. Conclusions}

The conclusions from the study results on the form of semiotic applications that the writers apply in Surah Mary include; semiotics of signification by Ferdinand de Saussure, semiotics of communication by Charles S. Peirce and semiotics of connotation by Roland Barthes.

\section{B. Implication}

This study implies that the semiotic reading of the Qur'an prioritizes the interpretation of the text in a synchronic and diachronic, denotative and connotative way. Hopefully, by this reading, religious and Islamic moderation could be achieved.

\section{REFERENCES}

Hamka, Tafsir al-Azhar juz XVI. Jakarta : PT. Citra Serumpun Padi, 2005.

Herwinarko, Stephanus Aswar. Semiologi; Kajian Teori Tanda Saussuran antara Semiologi Komunikasi dan Semiologi Signifikasi. Cet. I; Yogyakarta: Jalasutra, 2010.

Ibn Kașìr, Abū al-Fidā Ismā'il Ibn 'Umar. Tafsìr Ibn Katsìir . Cet. I; Jakarta: Pustaka Imam Syafi'I, 2004.

Imran, Ali. Semiotika al-Qur'an: Metode dan Aplikasi terhadap Kisah Yusuf. Cet. I; Yogyakarta: Teras, 2011.

Kamus Besar Bahasa Indonesia . Cet. I; Jakarta: Balai Pustaka, 2001.

Kementrian Agama RI, Alquran dan Terjemahnya. Cet. X; Bandung: CV Penerbit Dipenigoro, 2013.

M. Ardiansyah, Elemen-elemen Semiologi. Cet. I; Jogjakarta: IRCiSoD, 2012.

Muhajir, Noeng. Metodologi Penelitian Kualitatif. Cet. VIII; Yogyakarta: Rake Sarasin, 1996.

Rusmana, Dadang. Filsafat Semiotik. Cet. I; Bandung: Pustaka Setia, 2014.

Santoso, Puji. Ancangan Semiotik dan Pengkajian Susastra. Cet. I; Bandung: CV Angkasa: 2013.

Sobur, Alex Semiotika Komunkasi. Cet. IV; Bandung: Remaja ROsdakarya, 2009.

Sugiono, Metodelogi Penelitian Kuantitatif Kualitatif dan R\&D . Cet. VII; CV.Alvabeta, 2009.

Al-Ṭabari, Abū Ja'far Muhammad Ibn Jarìr. Tafsìr al-Tabarīi Jämi' al-Bayān 'an Ta'wìl ayy al-Qur'ān. Bairūt: Mu'assasah al-Risalah, $1415 \mathrm{H}$. 
Yunus, Mahmud. Kamus Arab-Indonesia. Cet. I; Jakarta: PT Mahmud Yunus wa Dzurriyah, 2010.

Al-Zamakhsyari, Abū al-Qāsim Mạ̣mūd bin 'Umar bin Muḥammad. al-Kasysyāf 'an

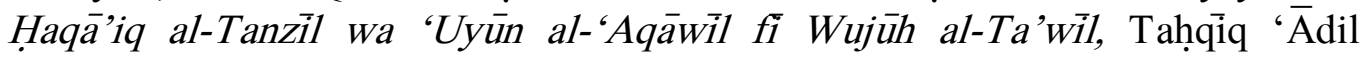
Ahmad wa 'Alì Ma’ự̣ Juz 1. Cet. I; Riyāḍ: Maktabah al-'Abayikān, 1998 M. 